\title{
Sugar cane nutrient requirements and the role of atmospheric deposition supplying supplementary fertilization in a Venezuelan sugar cane plantation
}

\author{
D. LÓPEZ-HERNÁNDEZ and D. SEQUERA \\ Laboratorio de Estudios Ambientales, Instituto de Zoología y Ecología Tropical, Facultad de Ciencias, \\ Universidad Central de Venezuela, Apartado 80249, Caracas, Venezuela \\ Corresponding author: D. López-Hernández; e-mail: danilo.lopez@ciens.ucv.ve \\ O. VALLEJO \\ Universidad Nacional Experimental de los Llanos Occidentales, Decanato de Postgrado, Guanare, \\ Estado Portuguesa, Venezuela
}

C. INFANTE

Laboratorio de Estudios Ambientales, Instituto de Zoología y Ecología Tropical, Facultad de Ciencias, Universidad Central de Venezuela, Apartado 80249, Caracas, Venezuela

Received February 3, 2012; accepted September 26, 2012

\begin{abstract}
RESUMEN
La región centro norte de Venezuela está caracterizada por lluvias de naturaleza ácida, cargadas de contaminantes que incluyen nutrientes, debido a la intensa actividad industrial y agrícola de la zona. Esta región presenta a su vez grandes extensiones de plantaciones de caña de azúcar. Una vez que la lluvia pasa por el dosel de bosques o de ecosistemas agrícolas, su composición química cambia, ya sea por absorción, lixiviación o lavado de iones depositados en el dosel. Este documento describe los cambios en la química de las aguas de lluvias después de pasar por el dosel de una plantación de caña de azúcar. En cuatro parcelas de $300 \mathrm{~m}^{2}$ ubicadas en un área experimental de 4.5 ha, plantadas con Saccharum officinarum, se instalaron colectores de agua de lluvia y de escurrimiento foliar. El estudio corresponde al análisis de crecimiento de la tercera soca del cultivo. El pH del agua de lluvia se incrementa cuando pasa por el dosel. La magnitud de los cambios fue importante y se relacionó parcialmente con las cantidades significativas de cationes que se lavan del dosel. Las entradas de $\mathrm{N}$ en el agroecosistema fueron altas $\left(25.25 \mathrm{~kg} \mathrm{ha}^{1} \mathrm{a}^{-1}\right)$ como consecuencia de la fertilización y quema local de la caña antes de su cosecha y la actividad industrial (petroquímica y fertilizantes) desarrollada en la zona. Las precipitaciones (húmeda y seca) representan una importante fuente de entradas de nutrientes a la plantación. En el caso de los macronutrientes (N, P y K) las entradas fueron altas y suplen una significativa fracción de los requerimientos del cultivo, lo mismo ocurre en el caso del zinc y del cobre.
\end{abstract}

\begin{abstract}
As a consequence of high industrial and agricultural activities, acidic rains loaded with pollutants - including nutrients - are characteristic of northern central Venezuela, a region dominated by sugar cane plantations. Canopies of forest and agricultural crops can modify the chemistry of rainfall through uptake, leaching and outwash of deposited ions. This paper describes the change in the chemistry of acid rains after passing through a sugar cane canopy. Four plots of $300 \mathrm{~m}^{2}$ within a 4.5 ha experimental area, planted with Saccharum officinarum had rain and throughfall collectors installed. The study corresponds to the analysis of the growing season of the third ratoon. The $\mathrm{pH}$ of the rain in the agroecosystem increased after passing through the canopy. The magnitudes of the changes were important and partially related to the significant amount of cations leached from the leaves or washed out from dry deposition to the leaves. $\mathrm{N}$ inputs for wet and dry deposition in the agroecosystem were high $\left(25.25 \mathrm{~kg} \mathrm{ha}^{-1} \mathrm{yr}^{-1}\right)$ as a consequence of the agricultural activity in the area, the local burning of sugar cane before cropping, and the location of the experimental area close
\end{abstract}


to petrochemical and fertilizer industries. Rainfall constitutes an important source of nutrient inputs to the sugar cane system. In the case of macronutrients (N, P and K) the inputs were high and supply an important fraction of plant nutrient needs, as occurs for zinc and copper.

Keywords: N-deposition, throughfall, foliar leaching, pollution, foliar fertilization.

\section{Introduction}

Acidic rains enriched with ammonium $\left(\mathrm{NH}_{4}\right)$, phosphorus $(\mathrm{P})$ and sulphur $(\mathrm{S})$ are characteristic of northern Venezuela (Morales et al., 1998), a region currently supporting sugar cane plantations where significant agricultural and industrial activities take place generating significant revenue annually.

Nitrogen (N) inputs $\left(\mathrm{NH}_{4}^{+}\right.$and nitrate $\left.\mathrm{NO}_{3}{ }^{-}\right)$in precipitation are considered of great importance in the $\mathrm{N}$ economy of natural ecosystems (López-Hernández et al., 2012), but in agroecosystems, those inputs are of lesser importance when compared with the $\mathrm{N}$ requirements for crop production (Stevenson, 1982; Thorburn et al., 2005). N and other nutrients present in precipitation and dry deposition can originate from a variety of natural and anthropogenic sources, including air pollution (Rodrigo et al., 2003). Emissions from anthropogenic pollution are beneficial, as some deposited elements are nutrients for forests and crops (López-Hernández et al., 2012), but harmful as well under certain polluted environments, e.g. where trace metal deposition is important (Pritsch et al., 2006).

Tree and agricultural crops canopies modify raindrop trajectories by partitioning the incident rainfall into throughfall and stemflow (Park and Cameron, 2008). A proportion of the incident rainfall is intercepted (I) by, and retained temporarily on leaf surface, branches and stems. Throughfall (TF) is the portion of rainfall $(\mathrm{P})$ that reaches the soil by passing directly or by dripping from the canopies (forest or crop plantations). These components may be linked by the relationship:

$I=P-T F$

Concerning precipitation chemistry, canopies of forests and agricultural crops can modify the chemistry of rainfall in different ways: (1) uptake and retention by the canopy, (2) removal and leaching of ions from leaves, or (3) changes in the rain waters when passing through the canopy (throughfall) by the wash out of dry deposition (Tukey, 1970; Rodrigo et al., 2003;
Perez-Marin and Menezes, 2008). The magnitude of the foliar leaching depends on a variety of factors: plant age, physiological state, plant composition and canopy morphology (Malek and Astel, 2007), but also on frequency, duration, intensity and chemical composition of the rainwater; moreover, in polluted areas the actual composition of the throughfall depends on the pollution source (Rodrigo et al., 2003).

The high primary production (ca. 60-100 ton ha ${ }^{-1}$ $\mathrm{yr}^{-1}$ ), and the particular plant architecture of the canopy of the sugar cane allow an important leaf interception of the income precipitation. Rainfall arriving sugar cane systems, in turn, might have a change in its chemical composition mainly due to throughfall processes, before it reaches the soil. However, few studies have tried to understand the changes in the chemistry of the atmospheric deposition through canopy interactions in a sugar cane agroecosystem during its development.

This paper describes the changes in the chemistry of acid tropical rainwater after passing through a sugar cane canopy along the development of their third ratoon. Particular emphasis is given to the quantification of the inputs of macronutrients $(\mathrm{N}$, $\mathrm{K}, \mathrm{P})$ and micronutrients $(\mathrm{Fe}, \mathrm{Mn}, \mathrm{Zn}$, and $\mathrm{Cu})$ in the agroecosystem. Therefore, we studied whether the element deposition (particularly for the macronutrients $\mathrm{N}, \mathrm{P}, \mathrm{K}$ ) constituted a relevant proportion of the nutrients retained in the sugar cane canopy.

\section{Material and methods}

\subsection{Study site}

The study was located in a sugar cane farm near San Felipe, Yaracuy state, central Venezuela $\left(10^{\circ}\right.$ $29^{\prime} 44^{\prime \prime} \mathrm{N}$ and $\left.68^{\circ} 31^{\prime} 44^{\prime \prime} \mathrm{W}\right)$. The experimental site corresponds to a tropical humid climate region (1400$1700 \mathrm{~mm}$ of precipitation) affected by marine aerosols.

Four plots of $300 \mathrm{~m}^{2}$ within an experimental area of 4.5 ha planted with Saccharum officinarum were selected for the installation of rain and throughfall collectors. Study corresponds to the analysis of the growing period of two sugar cane varieties (Puerto Rico 1028 [PR] and Venezuela 58-4 [V]). The soil is 
a Mollisols, Haplaquoll (fine loam, isohiperthermic, muscovite, montmorillonitic, kaolinitic) with a $\mathrm{pH}$ of 7.4, moderate to high effective cation exchange capacity (ECEC), moderate to high available and total $\mathrm{P}$ contents, and moderate $\mathrm{N}$ content.

\subsection{Collection of rain and throughfall waters and analysis}

Collection of rain and throughfall waters was weekly conducted during three consecutive years; however information here presented corresponds to the year of the third ratoon.

Bulk depositions (i.e., wet plus dry) were collected with plastic funnels of $18.5 \mathrm{~cm}$ internal diameter (PVC polyvinyl chloride) attached $4.5 \mathrm{~m}$ above soil surface and above the sugar cane canopies. The funnels were permanently open to the atmosphere; therefore, precipitation thus collected corresponds to bulk deposition as named by Eriksson (1953) and comprises the wet deposition flux and the dry deposition flux of gravitory sedimentation (Rodrigo et al., 2003). The funnels were connected to $2 \mathrm{~L}$ polyethylene terephtalate (PET) bottles, which were first acid-washed ( $\mathrm{HCl} \mathrm{50 \% )} \mathrm{and}$ then rinsed with demineralized water. Bulk deposition (BD) for chemical analysis was sampled during one year from five gauges located in the plots.

Throughfall waters were collected in PVC funnels attached $0.30 \mathrm{~m}$ above soil surface within the canopies connected to PET bottle collectors. In this study, due to the usual high variability of the throughfall measures, a total of twenty collectors were installed for regular sampling instead of the five installed for bulk collection. Nylon meshes were placed in the funnel necks, and at the end of tube and bottle connections to prevent insects or vegetal debris from falling inside the sampling collectors.

Net throughfall for a particular element (NTFe) corresponds to the modification of precipitation chemistry as water enters the system and is defined as $N T F e=T F e-B D e$, where $T F e$ and $B D e$ correspond to the amount of the element in throughfall and bulk deposition, respectively. More details of the methodology are presented in Infante et al. (1993) and López-Hernández et al. (2005).

\subsection{Chemical analysis}

After one day of collection, the samples were taken to the laboratory where $\mathrm{pH}$ was measured with a glass electrode. Water samples were then filtered through
$0.45 \mu \mathrm{m}$ pore size Millipore filters, and phenyl mercury acetate $\left(1 \mathrm{ml} \mathrm{L}^{-1}\right)$ was added as preservative. Samples were rejected when contaminated by debris. Two aliquots of each sample (one acidified with $1 \mathrm{ml} \mathrm{L}^{-1}$ pure $\mathrm{HNO}_{3}$ bidistilled with a quartz distiller) were kept for further analysis.

In the non-acidified samples, $\mathrm{NO}_{3}$ and $\mathrm{NH}_{4}$ in the waters were analyzed in a Technicon Auto Analyzer II (Technicon Industrial Systems, 1974) whereas P $\left(\mathrm{PO}_{4}^{-3}\right)$ was determined with the colorimetric method of Murphy and Riley (1962). Cations (Na, K, Ca and $\mathrm{Mg}$ ) were analyzed by atomic absorption in a Varian Techtron AA6.

Aliquot samples acidified with $\mathrm{HNO}_{3}$ (in order to avoid adsorption of micronutrients in the recipient walls) were kept at $4{ }^{\circ} \mathrm{C}$ until the micronutrient analysis was performed. Micronutrients (Fe, Mn, $\mathrm{Zn}$ and $\mathrm{Cu}$ ) in precipitation and throughfall waters were analyzed by flameless absorption spectroscopy, but without preconcentration; an HGA 2100 heated graphite atomizer (Perkin-Elmer) was employed.

Bulk deposition and throughfall waters were analyzed individually from several samples collected during a given month and averaged for monthly inputs as the product of bulk deposition and throughfall volumes, and monthly weighted average concentration of the element. The annual inputs of elements in incident rainfall (BDe) and throughfall (TFe) to the sugar cane plantation were expressed per unit area (ha).

\subsection{Statistical analyses}

Analyses were carried out with $t$-tests (Student $t$-test, $p<0.05$ ) for paired samples on the difference between monthly concentration of elements in precipitation and throughfall waters.

\section{Results}

\subsection{Developing of the sugar cane canopy and rain interception}

The monthly percentage of canopy interception increased sharply with the age of the plantation during the first five months (third ratoon, Fig. 1) until a maximum of $60.3 \%$, and then it fluctuated around that maximum (38.3-59.9\%). During the study period, the total precipitation measured was $1752 \mathrm{~mm}$, whereas the water volume estimated from the throughfall was $1124 \mathrm{~mm}$, which corresponds to $64 \%$ of the total precipitation. 


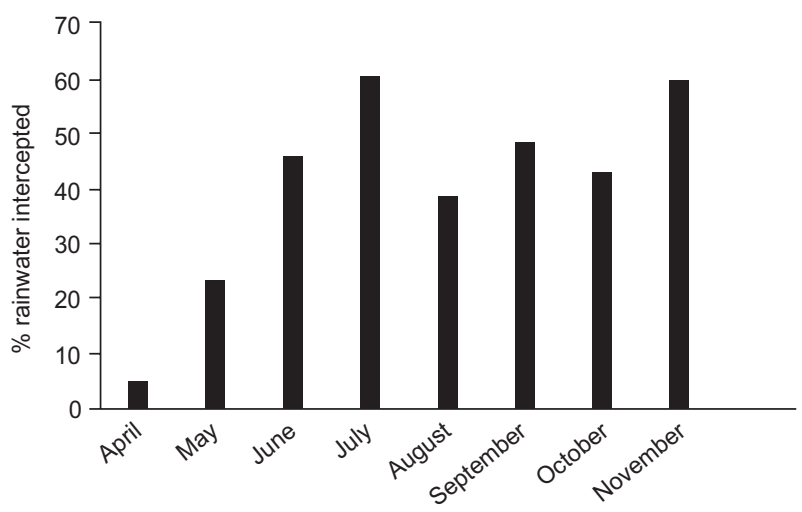

Fig. 1. Percentage of rainwater intercepted by the canopy in a sugarcane agroecosystem.

\subsection{The $\mathrm{pH}$ and base cation concentrations in rain- water}

The $\mathrm{pH}$ of bulk deposition in the sugar cane agroecosystem increased by 0.93 to $1.64 \mathrm{pH}$ units as it passed through the canopy (Table I). Those results may reflect the significant amount of cations leached from the leaves or washed out from materials deposited on the leaves and cane stems (Table I). Thus, throughfall waters were enriched in bases compared with bulk deposition, particularly after June (peak of the rainy season) when the sum of bases in the throughfall waters surpassed the values of the bulk deposition (Table I, Fig. 2).

The average monthly values for cations (Fig. 2) followed the order $\mathrm{Na}>\mathrm{K}>\mathrm{Mg}>\mathrm{Ca}$. The dominance of $\mathrm{Na}$ in precipitation reflects the deposition of marine aerosols in the studied area. $\mathrm{Na}$ and $\mathrm{K}$ in the precipitation water at the sugar cane agroecosystem (Fig. 2) showed an annual mean concentration of 1.87 and $1.41 \mathrm{mg} \mathrm{L}^{-1}$, respectively. $\mathrm{Mg}$ presented an intermediate concentration $\left(0.24 \mathrm{mg} \mathrm{L}^{-1}\right)$ whereas the $\mathrm{Ca}$ average concentration was the lowest $\left(0.12 \mathrm{mg} \mathrm{L}^{-1}\right)$.

\subsection{Net throughfall of cations}

There was a net positive throughfall of $\mathrm{Mg}$ from the canopy (more than twice the bulk deposition) and to a lesser extent for $\mathrm{Ca}$. In contrast, the $\mathrm{Na}$ concentration showed a net negative throughfall that was significantly different $(t$-test, $p<0.05)$ between deposition and throughfall from April to October (Fig. 2, Table II), whereas for $\mathrm{K}$ there was a small net negative throughfall (Table II); however, the canopy losses were high in the months of August to October (Fig. 2).

\subsection{Nitrogen and phosphorus concentrations in rain waters}

$\mathrm{NH}_{4}$ was the predominant $\mathrm{N}$ form in the precipitation water with a mean value of $1.29 \mathrm{mg} \mathrm{L}^{-1}$ (Fig. 3), but nitrate- $\mathrm{N}$ was not detectable in the majority of months (Fig. 3). $\mathrm{P}\left(\mathrm{PO}_{4}^{-3}\right)$ concentrations in rainwater ranged from 0.10 to $1.64 \mathrm{mg} \mathrm{L}^{-1}$ (Fig. 3). After passing through the sugar cane canopy there was a strong enrichment in nitrates in the throughfall compared with the bulk deposition (28.67), whereas in the case of $\mathrm{NH}_{4}$ and orthophosphate the annual concentrations of the bulk deposition decreased in a significant form due to canopy absorption (Table III).

\subsection{Net throughfall of nitrogen and phosphorus}

There was an important $\mathrm{N}$ fertilization (net negative throughfall) of the canopy through $\mathrm{NH}_{4}$ absorption. In contrast, the net positive throughfall of $\mathrm{NO}_{3}$

Table I. Monthly average $\mathrm{pH}$ and sum of cation concentrations $\left(\mu \mathrm{eq} \mathrm{L}^{-1}\right)$ in bulk deposition and throughfall in a sugarcane agroecosystem located in central northern Venezuela. Bulk deposition included wet and dry deposition collected above the sugarcane canopy.

\begin{tabular}{lccccc}
\hline Month & BD pH & TF pH & Sum of BD cations & Sum of TF cations & Sum of TF/BD cations \\
\hline April & 4.52 & 5.50 & 227 & 138 & 0.61 \\
May & 3.70 & 5.26 & 177 & 105 & 0.60 \\
June & 3.97 & 4.99 & 209 & 271 & 1.30 \\
July & 3.97 & 4.90 & 156 & 145 & 0.93 \\
August & 4.22 & 5.45 & 83 & 134 & 1.61 \\
September & 3.67 & 5.20 & 113 & 225 & 1.99 \\
October & 3.54 & 4.50 & 66 & 198 & 1.67 \\
November & 4.12 & 5.76 & 126 & 210 & 2.44 \\
December & 4.20 & 5.29 & 103 & 251 & \\
\hline
\end{tabular}

BD: bulk deposition; TF: throughfall. 

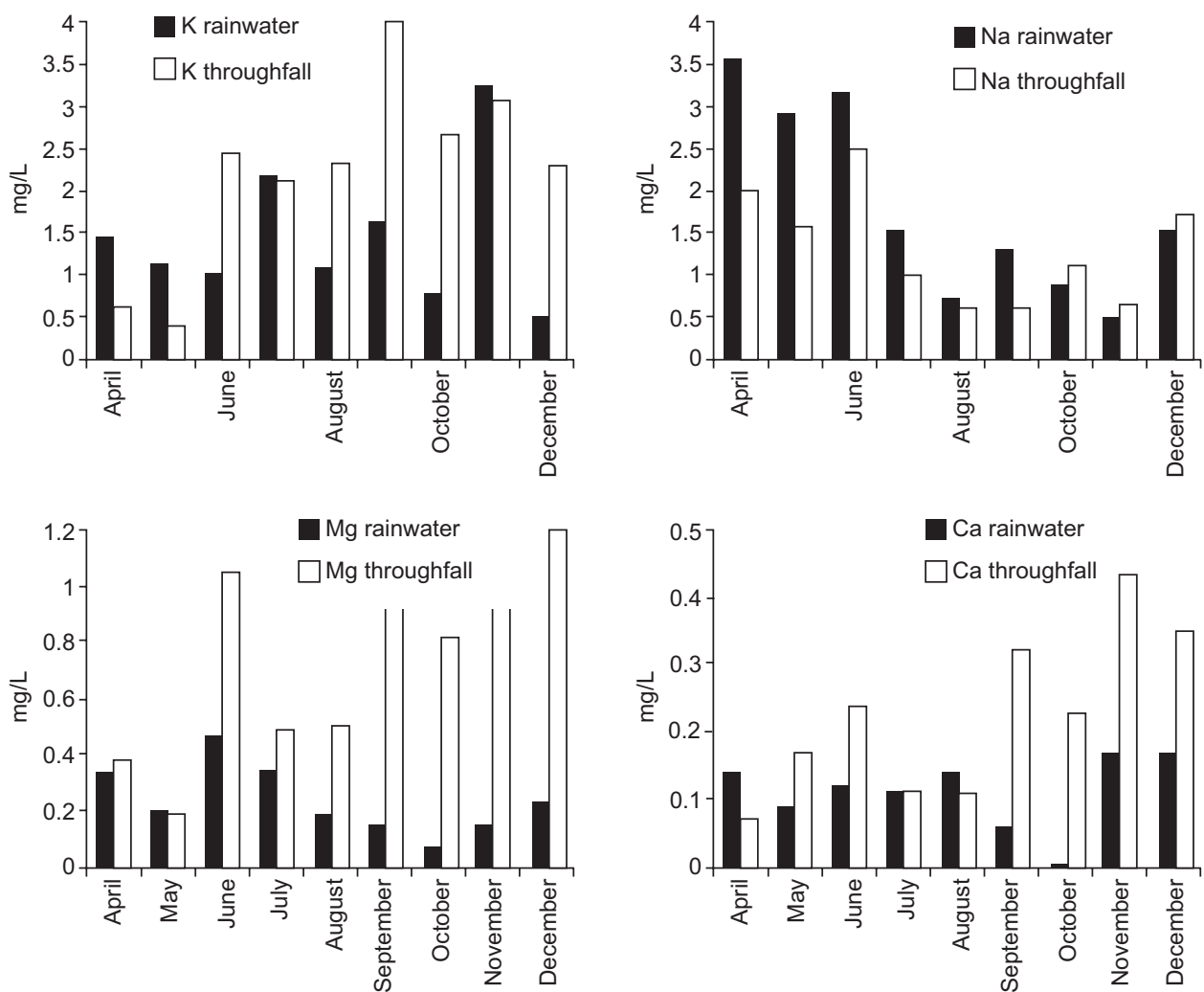

Fig. 2. Monthly weighted average concentrations of cations $\left(\mathrm{mg} \mathrm{L}^{-1}\right)$ in rain and throughfall waters.

indicates that $\mathrm{NO}_{3}$ was leached from the canopy (leaves and stem) in throughfall waters (Table II, Fig. 3), particularly in the months when $\mathrm{NO}_{3}$ was not detectable in bulk deposition. The important

Table II. Annual fluxes $\left(\mathrm{kg} \mathrm{ha}^{-1} \mathrm{yr}^{-1}\right)$ of nutrients in bulk deposition and throughfall, and net throughfall in a sugarcane agroecosystem located in central northern Venezuela. Significant differences $(t$-test, $\mathrm{P}<0.05)$ between bulk deposition and throughfall are shown in bold in the column "net throughfall".

\begin{tabular}{lccc}
\hline Element & $\begin{array}{c}\text { Bulk } \\
\text { deposition }\end{array}$ & Throughfall & $\begin{array}{c}\text { Net } \\
\text { throughfall }\end{array}$ \\
\hline $\mathrm{Na}$ & 24.92 & 14.34 & $\mathbf{- 1 0 . 5 8}$ \\
$\mathrm{K}$ & 22.54 & 21.54 & -1.00 \\
$\mathrm{Mg}$ & 3.34 & 7.89 & $\mathbf{4 . 5 5}$ \\
$\mathrm{Ca}$ & 1.93 & 2.45 & 0.52 \\
$\mathrm{~N}-\mathrm{NO}_{3}$ & 0.06 & 4.14 & $\mathbf{4 . 0 8}$ \\
$\mathrm{N}^{-N_{4}}$ & 25.19 & 9.30 & $\mathbf{- 1 5 . 8 9}$ \\
$\mathrm{P}_{4}\left(\mathrm{H}_{2} \mathrm{PO}_{4}^{-3}\right)$ & 14.71 & 4.84 & $\mathbf{- 9 . 8 7}$ \\
$\mathrm{Zn}$ & 0.633 & 0.269 & $\mathbf{- 0 . 3 6 4}$ \\
$\mathrm{Cu}$ & 0.104 & 0.098 & -0.006 \\
$\mathrm{Mn}$ & 0.131 & 0.062 & $\mathbf{- 0 . 0 6 9}$ \\
$\mathrm{Fe}$ & 0.263 & 0.201 & -0.062 \\
\hline
\end{tabular}

amounts of $\mathrm{P}\left(\mathrm{PO}_{4}^{-3}\right)$ entering the sugar cane system in the incident precipitation were retained in the canopy of the agroecosystem; therefore a negative annual throughfall of $9.87 \mathrm{~kg} \mathrm{P} \mathrm{ha}^{-1} \mathrm{yr}^{-1}$ was found (Table II).

\subsection{Trace metals concentrations in rainwater}

Figure 4 presents the weighted average concentrations of the trace metals analyzed (Fe, Mn, $\mathrm{Zn}$ and

Table III. Annual weighted average of macronutrients $\left(\mathrm{mg} \mathrm{L}^{-1}\right)$ and heavy metals $\left(\mu \mathrm{g} \mathrm{L}^{-1}\right)$ in bulk deposition and throughfall in a sugarcane agroecosystem located in central northern Venezuela.

\begin{tabular}{lccc}
\hline Element & $\mathrm{BD}$ & $\mathrm{TF}$ & $\mathrm{TF} / \mathrm{BD}$ \\
\hline $\mathrm{N}^{-N O_{3}}$ & 0.015 & 0.43 & 28.67 \\
$\mathrm{~N}-\mathrm{NH}_{4}$ & 1.88 & 1.00 & 0.53 \\
$\mathrm{P}-\left(\mathrm{H}_{2} \mathrm{PO}_{4}{ }^{-3}\right)$ & 0.76 & 0.43 & 0.57 \\
$\mathrm{Zn}$ & 40.1 & 25.3 & 0.63 \\
$\mathrm{Cu}$ & 6.2 & 8.9 & 1.43 \\
$\mathrm{Mn}$ & 8.9 & 6.0 & 0.67 \\
$\mathrm{Fe}$ & 15.6 & 19.5 & 1.25 \\
\hline
\end{tabular}

BD: bulk deposition; TF: throughfall. 

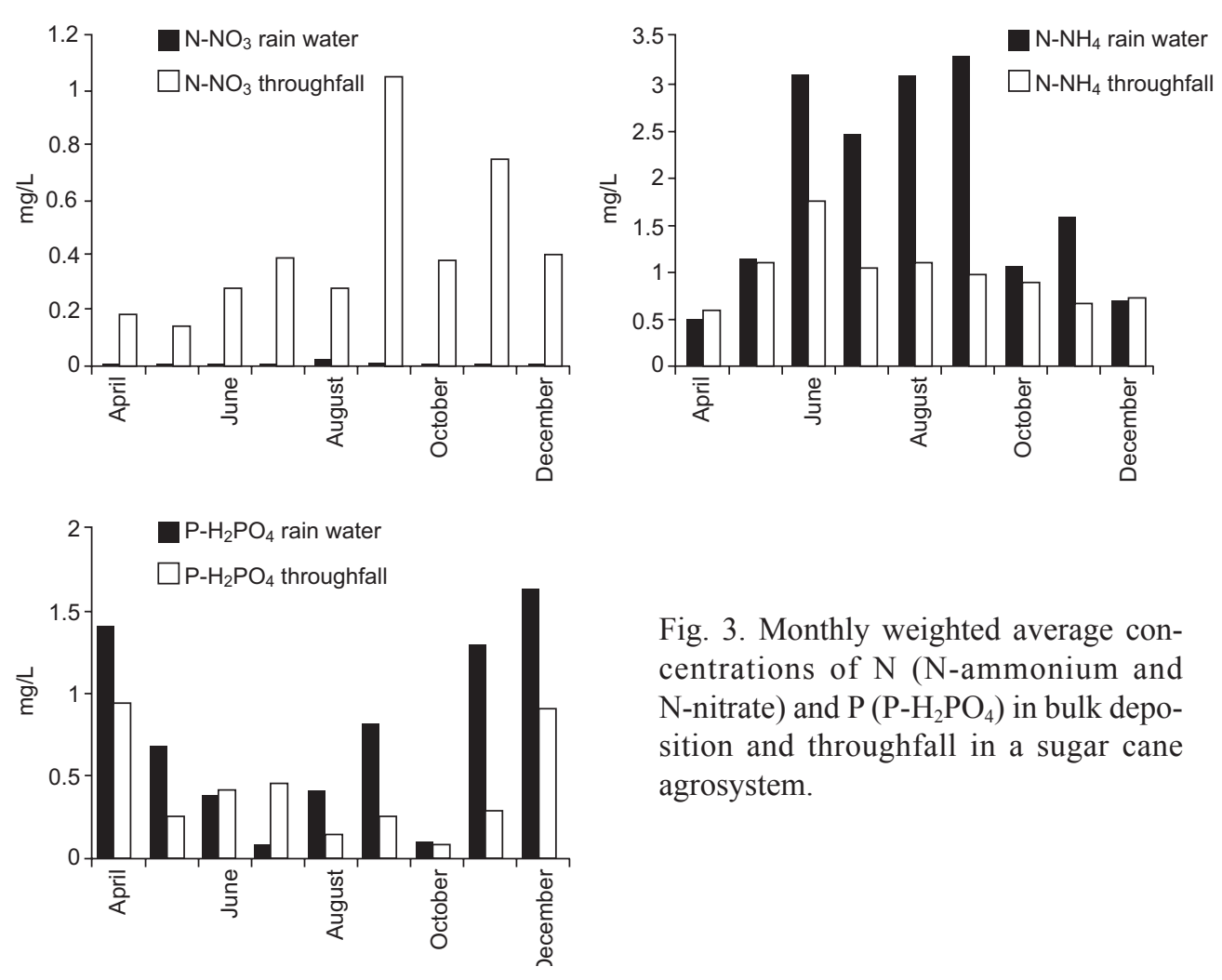

Fig. 3. Monthly weighted average concentrations of $\mathrm{N}$ ( $\mathrm{N}$-ammonium and $\mathrm{N}$-nitrate) and $\mathrm{P}\left(\mathrm{P}-\mathrm{H}_{2} \mathrm{PO}_{4}\right)$ in bulk deposition and throughfall in a sugar cane agrosystem.
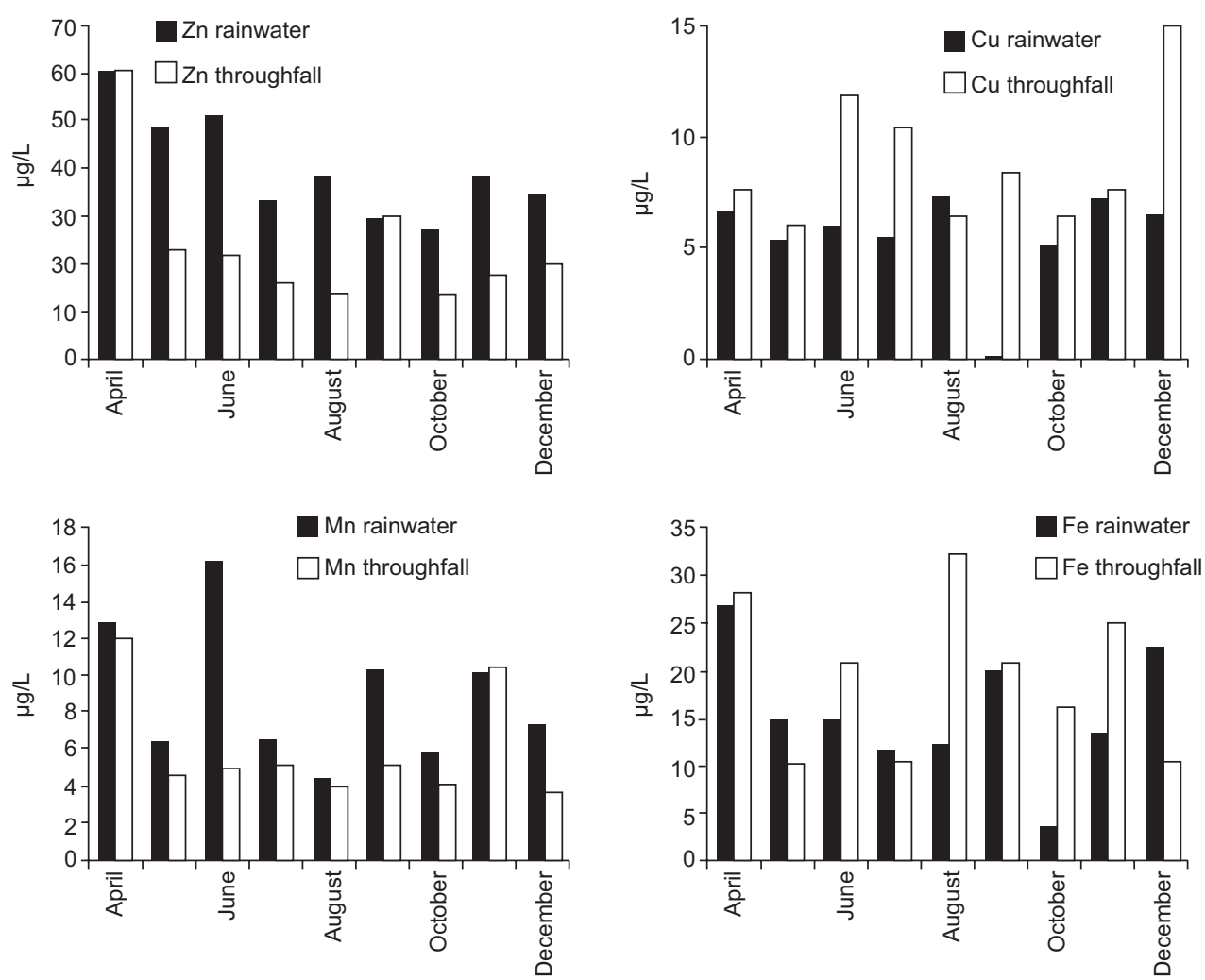

Fig. 4. Monthly weighted average concentrations of heavy metals in bulk deposition and throughfall in a sugar cane agroecosystem. 
$\mathrm{Cu}$ ) in the precipitation waters. $\mathrm{Zn}$ had the highest concentration followed by $\mathrm{Fe}$, while $\mathrm{Cu}$ and $\mathrm{Mn}$ presented similar values (Fig. 4). Throughfall waters were enriched in $\mathrm{Cu}$ and $\mathrm{Fe}$ compared with bulk deposition (Table III); on the contrary, the annual concentrations of bulk deposition decreased significantly in the case of $\mathrm{Zn}$ and $\mathrm{Mn}$ due to active canopy absorption (Table III).

\subsection{Net throughfall of trace metals}

Net throughfall deposition was negative for $\mathrm{Zn}, \mathrm{Mn}$ and Fe (Fig. 4, Table II), whereas in the case of $\mathrm{Cu}$, rain and throughfall depositions were almost similar. Net throughfall of $\mathrm{Mn}$ and Fe were moderately negative (62-69 $\mathrm{g} \mathrm{ha}^{-1} \mathrm{yr}^{-1}$ ), whereas for $\mathrm{Zn}$ it was strongly negative accounting for a significant foliar absorption (364 $\left.\mathrm{g} \mathrm{ha}^{-1} \mathrm{yr}^{-1}\right)$.

\section{Discussion}

\subsection{Development of the sugar cane canopy and rain} interception

Information corroborates the effect of crop development in rainwater interception. There is an initial increase of interception as the canopy develops, and then it stabilizes around $40 \%$ of interception when the canopy is fully developed (Fig. 1). After the fifth month of crop development, when the maximum interception is achieved, a high variability in interception measures is found (38.3-59.9\%) that is related to plant senescence. Thus, the incremental accumulation of dead materials (leaves and stems) relative to the living parts strongly affected rainwater interception (Dunne and Leopold, 1978). Rutter (1963) and Grimm and Fassbender (1981) have pointed out that successive and copious rain events contribute to saturation or overflooding of the canopy surface, consequently decreasing its interception capacity.

Although the information for canopy interception is copious in temperate and tropical forests, fewer studies of rainfall interception in grasslands have been done (Friesen et al., 2012). Leopoldo et al. (1981) reported $57 \%$ of precipitation interception in domestic sugar cane, a similar value to the one presented here, whereas in a recent publication Friesen et al. (2012), comparing rainfall interception in tropical hardwood trees and wild sugar cane Saccharum venosum, found interception values of $56.1 \%$ for the wild grass.
The interception value at maximum crop development reported here is lower than the values presented by Dezzeo and Chacón (2006) for tropical forests (77-80\%) and Rodrigo et al., (2003) in holm oak (Quercus ilex L.) Mediterranean forests (72-85\%); however, our value corresponds to the lower limit (62.1-94.5\%) of the range presented by Galoux et al., (1981) for different tropical forests and was higher compared with other gramineous plants (Ward, 1967). The interception values of the sugar cane agroecosystem are related with the architecture of the sugar cane canopy at the end of the growing season, which is characterized by abundant foliage with a receptacle formed between the stem and the basis of the foliage that helps to hold and therefore intercept rainwater within the canopy.

\subsection{The $\mathrm{pH}$ and base cation concentrations of rain- water}

Precipitation $\mathrm{pHs}$ in the studied plantation ranged from 3.54 to 4.52 (Table I), a common situation in northern central Venezuela as a consequence of high industrial (petrochemical and fertilizer production plants) and agricultural (crop fertilization and cattle raising) activities (Lewis and Weibezahn; 1981, Sequera et al., 1991; López-Hernández et al., 2012). In the rest of Venezuela, even in the absence of anthropogenic influence, precipitation is fairly acid (5.15.8) (Montes et al., 1987, López-Hernández 2008).

Concentrations of $\mathrm{Na}$ and $\mathrm{K}$ were higher than the values presented by Steinhardt and Fassbender (1979) in a cloud forest located in San Eusebio, Venezuela, and by López-Hernández et al. (1994) in a flooded savanna ecosystem in Mantecal, Venezuela located far from the ocean and in a more pristine environment. On the contrary, Steinhardt and Fassbender (1979) in a forest site at San Eusebio, Venezuela and López-Hernández et al. (1994) at Mantecal, Venezuela reported higher annual averages for $\mathrm{Ca}$ and $\mathrm{Mg}$. In a pristine forest ecosystem at the Canaima National Park, located in Gran Sabana, southeastern Venezuela, Dezzeo and Chacón (2006) reported very low mean concentration of cations $(0.04$ and $0.11 \mathrm{mg} \mathrm{L}^{-1}$ for $\mathrm{Ca}$ and $\mathrm{K}$, respectively) in incident waters.

\subsection{Changes in $p H$ and bases in the throughfall waters \\ The $\mathrm{pH}$ of bulk deposition in the sugar cane agro- ecosystem increased as it passed through the canopy}


(Table I). These results may reflect the significant amount of cations leached from the leaves or washed out from materials deposited on the leaves and cane stems from terrestrial dust (Table I), though we cannot separate both effects based on the information obtained. Throughfall waters were enriched in bases compared with bulk deposition, particularly after June (peak of the rainy season) when the sum of bases in the throughfall waters surpassed the values of the bulk deposition (Table I, Fig. 2). Similar information is presented by Rodrigo et al. (2003) for Mediterranean forests that receive African red rains, which were responsible for most of the inputs of alkalinity and base cations inputs from bulk deposition. However, the precipitations in the Mediterranean environment were more enriched in $\mathrm{Ca}$ and $\mathrm{Mg}$ compared with this tropical site.

\subsection{Net throughfall of cations}

Net throughfall differs among cations, thus there was a net positive throughfall of $\mathrm{Mg}$ from the canopy and to a lesser extent for $\mathrm{Ca}$. In contrast, $\mathrm{Na}$ concentration showed a net negative throughfall that was significantly different ( $t$-test, $p<0.05$ ) between deposition and throughfall from April to October (Fig. 2, Table II), whereas for K there was a small net negative throughfall (Table II). However, canopy losses were high in the months of August to October (Fig. 2).

In two polluted forest sites in the México City air basin, Pérez-Suárez et al. (2008) reported a net positive throughfall deposition of $\mathrm{Ca}, \mathrm{Mg}$ and $\mathrm{K}$. Pérez-Marín and Menezes (2008) reported important $\mathrm{K}$ inputs to the soil from the throughfall waters in an agroforestry system with Gliricidia sepium in the semi-arid northeastern Brazil. Moreover, Dezzeo and Chacón (2006) reported that the low mean concentration of cations in precipitation waters was significantly higher (positive throughfall) after the passage through the forest canopy in a pristine forest ecosystem in the Canaima National Park, Gran Sabana, southeastern Venezuela.

\subsection{Nitrogen and phosphorus in rainwaters}

$\mathrm{NH}_{4}$ was the predominant $\mathrm{N}$ form (mean value 1.29 $\mathrm{mg} \mathrm{L}^{-1}$ ) in the precipitation water, but nitrate-N was not detectable in the majority of months (Fig. 3). Steinhardt and Fassbender (1979) in the cloud forest of San Eusebio, Venezuela, located about $300 \mathrm{~km}$ from the experimental site, and also affected by petrochemical activity, reported a lower $\mathrm{N}$ concentration (0.64 $\mathrm{mg} \mathrm{L}^{-1}$, mostly $\mathrm{NH}_{4}$ ). In Venezuelan more pristine environments at Gran Sabana, very much lower $\mathrm{N}$ concentration in incident waters $\left(0.04 \mathrm{mg} \mathrm{L}^{-1}\right)$ has been reported (Dezzeo and Chacón, 2006).

The $\mathrm{P}\left(\mathrm{PO}_{4}^{-3}\right)$ concentrations in rainwater ranged from 0.10 to $1.64 \mathrm{mg} \mathrm{L}^{-1}$ (Fig. 3). The values exceeded the information generally presented in the literature, which are about $0.05 \mathrm{mg} \mathrm{L}^{-1}$. Concentrations of $\mathrm{P}\left(\mathrm{PO}_{4}^{-3}\right)$ in rainfall are much affected by ash deposition, since the higher concentrations correspond to the period from November to March (Fig. 3), when the sugar cane plantations are burned in the areas located in the neighborhood of the experimental plot (Sequera et al., 1991).

\subsection{Changes in nitrogen and phosphorus contents in the throughfall waters}

There was an important $\mathrm{N}$ fertilization (net negative throughfall) of the canopy through $\mathrm{NH}_{4}$ absorption. In contrast, the net positive throughfall of $\mathrm{NO}_{3}$ indicates that $\mathrm{NO}_{3}$ was leached from the canopy (leaves and stem) in throughfall waters (Table II, Fig. 3), particularly in the months when $\mathrm{NO}_{3}$ was no detectable in bulk deposition. In two polluted forest sites in the México city air basin, Pérez-Suárez et al. (2008) reported also a negative throughfall deposition of $\mathrm{NH}_{4}$ under fir and pine canopies, whereas Rodrigo et al. (2003) reported a relative low negative annual throughfall of 1.64 and $1.61 \mathrm{~kg} \mathrm{ha}^{-1} \mathrm{yr}^{-1}$ of $\mathrm{NO}_{3}$ and $\mathrm{NH}_{4}$, respectively, for Mediterranean forests. The important amounts of $\mathrm{P}$ entering the sugar cane system in the incident precipitation were retained in the canopy of the sugar cane agroecosystem; therefore a negative annual throughfall of $9.87 \mathrm{~kg} \mathrm{P} \mathrm{ha}^{-1} \mathrm{yr}^{-1}$ was found (Table II).

\subsection{Trace metals in rainwaters}

The weighted average $\mathrm{Zn}$ concentration in precipitation $\left(40.1 \mu \mathrm{g} \mathrm{L}^{-1}\right)$ was higher in the sugar cane agroecosystem than the values presented in tropical environments by Steinhardt and Fassbender (1979) in a cloud forest $\left(2.4 \mu \mathrm{g} \mathrm{L}^{-1}\right)$, López-Hernández (2008) in a seasonally flooded Venezuelan savanna (28.6 $\mu \mathrm{g} \mathrm{L}^{-1}$ ), and McColl (1981) in a temperate eucalypt forest $\left(16.1 \mu \mathrm{g} \mathrm{L}^{-1}\right)$, but lower than $\mathrm{Zn}$ concentration reported by Golley et al. (1975) in a Panamanian rain tropical forest $\left(44 \mu \mathrm{g} \mathrm{L}^{-1}\right)$, and by 
Liu et al. (2005) in the southern Yellow sea, China $\left(60-150 \mu \mathrm{g} \mathrm{L}^{-1}\right)$. In pristine environments, the weighted average $\mathrm{Zn}$ concentration in precipitation greatly surpasses the $\mathrm{Cu}$ concentrations (Driscoll et al., 1994; Liu et al., 2005; Muezzinoglu and Cukurluoglu, 2006).

The weighted average $\mathrm{Cu}$ concentration in rainwater (about $8.3 \mu \mathrm{g} \mathrm{L}^{-1}$ ) is higher than the values presented by Steinhardt and Fassbender (1979) in San Eusebio, Venezuela $\left(2.79 \mu \mathrm{g} \mathrm{L}^{-1}\right)$ and lower than the information given by Golley et al. (1975) for the Panamaniam forest ecosystem $\left(24.0 \mu \mathrm{g} \mathrm{L}^{-1}\right)$ and by Muezzinoglu and Cukurluoglu (2006) in Izmir, Turkey $\left(19.7 \mu \mathrm{g} \mathrm{L}^{-1}\right)$. Cu mean concentration is however about the values presented by López-Hernández (2008) in a flooded savanna $\left(12.1 \mu \mathrm{g} \mathrm{L}^{-1}\right)$ and Liu et al. (2005) in a coastal region in the southern Yellow sea, China (3-15 $\left.\mu \mathrm{g} \mathrm{L}^{-1}\right)$. Fe and Mn concentrations were much lower than values reported by Steinhardt and Fassbender (1979) in San Eusebio, Venezuela.

\subsection{Element inputs at the sugar cane agroecosystem} The study site is near the sea; therefore, the cation concentrations in rainwater are affected by marine aerosols, although terrestrial dusts can also affect rainwater composition. $\mathrm{Na}$ and $\mathrm{K}$ inputs were high (24.92 and $22.54 \mathrm{~kg} \mathrm{ha}^{-1} \mathrm{yr}^{-1}$, respectively, Table II) when compared with other Venezuelan ecosystems, whereas in the cases of $\mathrm{Mg}$ and $\mathrm{Ca}$ the rain inputs (3.34 and $1.93 \mathrm{~kg} \mathrm{ha}^{-1} \mathrm{yr}^{-1}$, respectively) were lower and not much different than other Venezuelan sites.

Although nitrates were leached in throughfall waters (Fig. 3, Table II), N balance revealed significant $\mathrm{N}$ fertilization of the leave canopy (leaves and stem) through $\mathrm{NH}_{4}^{+}$absorption (Table II). Nitrogen inputs $\left(25.25 \mathrm{~kg} \mathrm{ha}^{-1} \mathrm{yr}^{-1}\right)$ for wet and dry deposition, mostly in the $\mathrm{NH}_{4}{ }^{+}$form $(25.19 \mathrm{~kg}$ $\mathrm{NH}_{4}{ }^{+} \mathrm{ha}^{-1} \mathrm{yr}^{-1}$, Table II), were high compared with other ecosystems. This is, no doubt, due to the high agricultural (fertilization, cattle raising and burning before cropping of the plantation) and industrial (petrochemical and fertilizer production plants) activities near the experimental area. In Venezuelan savannas distant from urban activities, mineral nitrogen inputs by precipitation, on the contrary, ranged from 2.2 to $6.2 \mathrm{~kg} \mathrm{~N} \mathrm{ha}^{-1} \mathrm{yr}^{-1}$ (López-Hernández et al., 2012).

The high amounts of $\mathrm{P}$ entering the sugar cane system as bulk deposition (Table II) account for a high $\mathrm{P}$ input $\left(14.71 \mathrm{~kg} \mathrm{ha}^{-1} \mathrm{yr}^{-1}\right)$, most of it $(11.01 \mathrm{~kg}$ $\left.\mathrm{ha}^{-1} \mathrm{yr}^{-1}\right)$ in months when active burning of sugar cane plantations is taking place (November to April, Fig. 3); therefore, dry deposition of phosphate salts might be occurring in the area.

$\mathrm{Zn}$ input at sugar cane agroecosystem $\left(633 \mathrm{~g} \mathrm{ha}^{-1}\right.$ $\mathrm{yr}^{-1}$ ) was similar to the value presented for Mantecal's savannas ( $595 \mathrm{~g} \mathrm{ha}^{-1} \mathrm{yr}^{-1}$ ) by López-Hernández (2008), much higher than the value $\left(30 \mathrm{~g} \mathrm{ha}^{-1} \mathrm{yr}^{-1}\right)$ reported by Steinhardt and Fassbender (1979) for a cloud forest located at San Eusebio, Venezuela, and similar to the value presented by Liu et al. (2005) in a coastal region of the southern Yellow sea (428 g $\left.\mathrm{ha}^{-1} \mathrm{yr}^{-1}\right)$. However, $\mathrm{Zn}$ input at the agroecosystem was very much lower than the value presented by Heinrichs and Mayer (1977) in an industrialized Central European forest ecosystem (3900 $\left.\mathrm{g} \mathrm{ha}^{-1} \mathrm{yr}^{-1}\right)$. Copper input in the sugar cane plantation $(97.8 \mathrm{~g}$ $\mathrm{ha}^{-1} \mathrm{yr}^{-1}$ ) also exceeded the $45 \mathrm{~g} \mathrm{ha}^{-1} \mathrm{yr}^{-1}$ presented for San Eusebio, Venezuela (Steinhardt and Fassbender 1979) and was under the values presented by Heinrich and Mayer (1977) in a heavy industrialized European forest ecosystem (224 $\left.\mathrm{g} \mathrm{ha}^{-1} \mathrm{yr}^{-1}\right)$ and by López-Hernández (2008) in the savannas of Mantecal, Venezuela (227 $\left.\mathrm{g} \mathrm{ha}^{-1} \mathrm{yr}^{-1}\right)$. Annual deposition of iron $\left(263 \mathrm{~g} \mathrm{ha}^{-1} \mathrm{yr}^{-1}\right)$ is much lower than the reported Steinhardt and Fassbender (1979) at San Eusebio, Venezuela. Manganese (Mn) input in precipitation water (131 $\mathrm{g} \mathrm{ha}^{-1} \mathrm{yr}^{-1}$ ) was lower than values reported in other tropical areas (Steinhardt and Fassbender, 1979).

\subsection{Nutrient inputs in relation to sugar cane nu- trient requirements}

Bulk deposition of polluted areas might be an important source of nutrient inputs to plants, which helps to cope with their nutrient needs. By using information already published concerning the macro- and micronutrient requirements (e.g., amount of the element contained in stems, green leaves and roots at the peak of maximum development) of the sugar cane varieties examined in this study (López-Hernández et al., 1993; Vallejo-Torres, 1988) we have found that in the case of the micronutrients, all the $\mathrm{Zn}$ absorbed from bulk precipitation would be in excess $(217 \%)$ of sugar cane requirements (Table IV). Cu demand by the crop is also well covered $(48.7 \%)$ by this mechanism; however, much less of the $\mathrm{Mn}, \mathrm{K}$ and $\mathrm{Fe}(9.9,5.0$ and $1.7 \%$, respectively) required by the sugar cane can be obtained by bulk precipitation. 
Table IV. Nutrient inputs in bulk deposition and nutrient requirements in a sugarcane agroecosystem located in central northern Venezuela. The $\mathrm{N}$ and P requirements were taken from López-Hernández et al. (1993) and micronutrient requirements from Vallejo-Torres (1988).

\begin{tabular}{lccc}
\hline Element & $\begin{array}{c}\text { Precipitation } \\
\text { input }\left(\mathrm{kg} \mathrm{ha}^{-1}\right)\end{array}$ & $\begin{array}{c}\text { Requirement } \\
\left(\mathrm{kg} \mathrm{ha}^{-1}\right)\end{array}$ & $\begin{array}{c}\text { Percent of requirement } \\
\text { from bulk deposition }\end{array}$ \\
\hline $\mathrm{Zn}$ & 0.666 & 0.306 & 217 \\
$\mathrm{Cu}$ & 0.098 & 0.201 & 48.7 \\
$\mathrm{Mn}$ & 0.178 & 1.791 & 9.9 \\
$\mathrm{Fe}$ & 0.440 & 25.637 & 1.7 \\
$\mathrm{~N}$ & 25.3 & 228.0 & 11.1 \\
$\mathrm{P}-\left(\mathrm{H}_{2} \mathrm{PO}_{4}^{-3}\right)$ & 15.0 & 62.0 & 24.2 \\
$\mathrm{~K}$ & 22.5 & 453.0 & 5.0 \\
\hline
\end{tabular}

The $\mathrm{N}$ input of rain water $\left(25.25 \mathrm{~kg} \mathrm{ha}^{-1} \mathrm{yr}^{-1}\right)$ represents around $11 \%$ of the $\mathrm{N}$ requirements $(228 \mathrm{~kg}$ $\mathrm{ha}^{-1} \mathrm{yr}^{-1}$ ) for biomass production of the sugar cane plantation while in the case of $\mathrm{P}$ the input as bulk deposition $\left(15 \mathrm{~kg} \mathrm{ha}^{-1} \mathrm{yr}^{-1}\right)$ represents $24 \%$ of the $\mathrm{P}$ requirements $\left(62 \mathrm{~kg} \mathrm{ha}^{-1} \mathrm{yr}^{-1}\right)$ of the varieties studied.

\section{Conclusions}

Incident rainfall constitutes an important source of nutrient inputs to the sugar cane system studied. In the case of macronutrients ( $\mathrm{N}$ and $\mathrm{P}$ ) the inputs were considerable when compared with other tropical regions and supply an important fraction of plant nutrient requirements; a similar situation was recorded in the case of the micronutrients analyzed particularly for zinc and copper. Although the input of $\mathrm{K}$ was important, the high demand of the sugar cane for this element makes the contribution marginal. We did not register Na uptake, however a significant proportion of the Na coming with the bulk deposition was retained in the canopy (Table II). About 10\% of the Mn needs can be covered by rainfall input, whereas in the case of iron, the precipitation supply is negligible compared with the plant's needs. In the agroecosystem, $\mathrm{Mg}$ and $\mathrm{K}$ concentrations increased considerably during the passage of rainwater through the canopy, suggesting that these elements tend to be leached from plant tissues and were mobile, particularly at the end of the growing season.

\section{Acknowledgements}

The technical assistance of Lic. M. Niño and Mr. F. Tovar are acknowledged. The research received financial support from CENAZUCA, Consejo de Desarrollo Científico y Humanístico $(\mathrm{CDCH})$ and
Consejo Nacional de Ciencia y Tecnología (Conicit). Thanks to Dr. Lucy Sheppard (CEH Edinburgh Bush Estate Penicuik) for the revision of a previous version of this manuscript. One anonymous reviewer provided useful comments on an earlier draft that allowed us to improve the quality of the final manuscript.

\section{References}

Dezzeo N. and N. Chacón, 2006. Nutrient fluxes in incident rainfall, throughfall and stemflow in adjacent primary and secondary forests of the Gran Sabana, southern Venezuela. For. Ecol. Manag. 234, 218-226.

Driscoll C., J. Otton and Å. Iverfeldt, 1994. Trace metals speciation and cycling. In: Biogeochemistry of small catchments: A tool for environmental research (B. Moldan and J. Cerný, Eds.). Chapter 13. John Wiley and Sons, Chichester, New York, Brisbane, Toronto, Singapore, pp. 343-360 (SCOPE 51).

Dunne T. and L. B. Leopold, 1978. Water in environmental planning. W. H. Freeman, 818 pp.

Eriksson E, 1953. Composition of atmospheric precipitation. Tellus 4, 215-232.

Friesen P., A. Park and A. Sarmiento-Serrud, 2012. Comparing rainfall interception in plantation trials of six tropical hardwood trees and wild sugar cane Saccharum spontaneous L. Ecohydrology, doi:10.1002/eco.1297.

Galoux A., P. Benecke, G. Gietl, H. Hager, C. Kayser, O. Kiese, K.R. Knoer and C.E. Murphy, 1981. Radiation, heat, water and carbon dioxide balances. In: IBP $23 \mathrm{D}$ (E. Reichle, Ed.). Cambridge University Press, New York, pp. 87-204.

Golley F. B., J. T. McGinnis, R. G. Clements, G. I. Child and M. J. Duever, 1975. Mineral cycling in a tropical rain forest ecosystem. University of Georgia Press, Athens, $248 \mathrm{pp}$. 
Grimm V. and H. W. Fassbender, 1981. Ciclos biogeoquímicos de un ecosistema de los Andes Occidentales de Venezuela. III. Ciclo hidrológico y translocación de elementos químicos con el agua. Turrialba 31, 89-99.

Heinrichs H. and R. Mayer, 1977. Distribution and cycling of major and trace elements in two Central European forest ecosystems. J. Environ. Qual. 6, 402- 407.

Infante C., D. López-Hernández, E. Medina and G. Escalante, 1993. Distribución de las formas inorgánicas del nitrógeno en los flujos hídricos de un agroecosistema tropical. Ecotrópicos 6, 13-23.

Leopoldo P. R., A. de P. Sousa and S. Tuacek Filho, 1981. Interceptação da água de chuva em cultura da cana-deaçúcar. Brasil Açucareiro 98, 9-16.

Lewis W. M. and F. H. Weibezahn, 1981. Acid rain and major seasonal variation of hydrogen ion loading in a tropical watershed. Acta Cient. Venez. 32, 236-238.

Liu C. H., G. Zhang, H. Ren and J. Zhang, 2005. Distribution of heavy metals and nutrients in rainwater in coastal regions between the southern Yellow Sea and East China Sea. Ch. J. Oceanol. Limn. 23, 230-237.

López-Hernández D., E. Medina, C. Infante, D. Sequera, M. Niño and O. Vallejo-Torres, 1993. Nutrient cycles in a sugarcane agroecosystem. In: Soil biota, nutrient cycling, and farming systems (M. G. Paoletti, W. Foissner, D. Coleman, Eds.). Lewis Publishers, Florida, pp. 147-156.

López-Hernández D., M., García and M. Niño, 1994. Input and output of nutrients in a diked flooded savanna. $J$. App. Ecol. 31, 303-312.

López-Hernández D., C. Infante and E. Medina, 2005. Balance de elementos en un agroecosistema de caña de azúcar: I. Balance de nitrógeno. Tropicultura 23, 212-219.

López-Hernández D., 2008. Biogeochemistry and cycling of zinc and copper in a dyked seasonally flooded savanna. Chem. Ecol. 24, 387-399.

López-Hernández D., D. Sequera, O. Vallejo and C. Infante, 2012. Atmospheric nitrogen deposition can provide supplementary fertilization to sugar cane crops in Venezuela. Chapter 21. In: Nitrogen deposition, critical loads and biodiversity (M. A. Sutton, K. E. Mason, L. J. Sheppard, H. Sverdrup, R. Haeuber, W. K. Hicks, Eds.). Proceedings of the International Nitrogen Initiative Workshop, Edinburgh, U.K. (in press)

Małek S. and A. Astel, 2007. The effect of stand age on throughfall chemistry in spruce stands in the Potok Dupniański catchment in the Silesian Beskid mountains, southern Poland. Impacts of air pollution and climate change on forest ecosystems. Scientific World Journal 7, 181-191.

McColl G. C., 1981. Trace elements in the hydrologic cycle of a forest ecosystem. Plant Soil 62, 337-349.

Montes R., J. J. San José and J. García-Miragaya, 1987. pH of bulk precipitation during three consecutive annual courses in the Trachypogon savannas of the Orinoco Llanos, Venezuela. Tellus 37B, 304-307.

Morales, J.A., C. Bifano and A. Escalona, 1998. Atmospheric deposition of $\mathrm{SO}_{4}-\mathrm{S}$ and $\left(\mathrm{NH}_{4}+\mathrm{NO}_{3}\right)-\mathrm{N}$ at two rural sites in the western Maracaibo Lake Basin, Venezuela. Atmos. Environ. 32, 3051-3058.

Muezzinnoglu A. and S. Cukurluoglu, 2006. Deposition of heavy metals in a Mediterranean climate area. Atmos. Res. 81, 1-16.

Murphy J. and J. Riley, 1962. A modified single solution method for the determination of phosphate in natural waters. Anal. Chim. Acta 27, 31-36.

Park A. and J. L. Cameron, 2008. The influence of forest traits on throughfall and stemflow in five tropical trees growing in a Panamaniam plantation. Forest Ecol. Manag. 255, 1915-1925.

Perez-Marin A. M. and R. S. C. Menezes, 2008. Ciclagem de nutrientes via precipitação pluvial total. interna e escoamento pelo tronco em sistema agroforestal com Gliricidia sepium. Ver. Brás. Ciênc. Solo 32, $2573-$ 2579.

Pérez-Suárez M., M. E. Fenn, V. M. Cetina-Alcala and A. Aldrete, 2008. The effects of canopy cover on throughfall and soil chemistry in two forest sites in the Mexico City air basin. Atmósfera 21, 83-100.

Pritsch K., M. S. Günthardt-Goerg, J. C. Munch and M. Schloter, 2006. Influence of heavy metals and acid rain on enzymatic activities in the mycorrhizosphere of model forest ecosystems. For. Snow Landsc. Res. 80, 289-304.

Rodrigo A., A. Avila and F. Roda, 2003. The chemistry of precipitation. Throughfall and stemflow in two holm oak (Quercus ilex L.) forest under a contrasted pollution environment in NE Spain. Sci. Total Environ. 305, 195-205.

Rutter A. J, 1963. Studies in the water relations of Pinus sylvestris in plantations conditions. I. Measurements of rainfall and interception. J. Ecol. 51, 191-203.

Sequera D., D. López-Hernández and E. Medina, 1991. Phosphorus dynamics in a sugar-cane crop. In: Phosphorus cycles in terrestrial and aquatic ecosystems (H. Tiessen, D. López-Hernández, I. Salcedo, Eds.). Proceedings of the Regional Workshop 3: South and 
Central America, organized by the Scientific Committee on Problems of the Environment (SCOPE) and the United Nations Environmental Programme (UNEP), Universidad Central de Venezuela, Maracay, pp. 243-251.

Steinhardt U. and H. W. Fassbender, 1979. Características y composición química de las lluvias de los Andes occidentales de Venezuela. Turrialba 29, 175 -182.

Stevenson F. J, 1982. Origin and distribution of nitrogen in soil. In: Nitrogen in agricultural soils (F. J. Stevenson, Ed.). American Society of Agronomy, Wisconsin, pp. 1-39 (Agronomy Series 22).
Technicon Industrial Systems, 1973. Nitrate and nitrite in water. Technicon Industrial Systems, Tarrytown, N.Y. Thorburn P. J., E. A. M. Meier and M. E. Probert, 2005. Modeling nitrogen dynamics in sugarcane systems: Recent advances and applications. Field Crop. Res. 92, 337-351.

Tukey H. B, 1970. The leaching of substances from plants. Ann. Rev. Plant Physio. 21, 305-322.

Vallejo-Torres O., 1988. Ciclaje de micronutrientes (Zn, $\mathrm{Cu}, \mathrm{Mn}$ y $\mathrm{Fe}$ ) en un agroecosistema de caña de azúcar. Ph.D. Thesis. Universidad Central de Venezuela, 258 pp. Ward R. C., 1967. Principles of hydrology. McGraw-Hill, New York. 